\title{
Investment Security Management in Transition Economies: Legal and Organizational Aspects
}

\begin{abstract}
Submitted 07/02/20, $1^{\text {st }}$ revision 01/03/20, $2^{\text {nd }}$ revision 28/03/20, accepted $15 / 04 / 20$

$$
\begin{gathered}
\text { T.O. Vlasenko }{ }^{1} \text {, R.F. Chernysh }{ }^{2}, \text { A.V. Dergach } \\
\text {, } \\
\text { T.V. Lobunets }{ }^{4} \text {, O.B. Kurylo }
\end{gathered}
$$

Abstract:

Purpose: There are significant differences between countries in transition from socialism to market economy, and hence differences in investment flows. As a result, the level of economic growth, competitiveness, and integration into the world markets differs significantly. Different transformation strategies, economic policies, and the level of openness of the economy explain the differences between countries. It is revealed that the level of political rights, civil liberties and economic freedom significantly affect investment flows. The aim of this article is to highlight these differences and evaluate them.

Design/Methodology/Approach: Data from 18 countries in transition are used to analyze investment security management.

Findings: The study has found that countries in transition have a low level of investment flows and a low level of investment security. On average, net investment inflows account for $3.5 \%$ of GDP. There is a positive relationship between investment outflows and gross capital formation, gross savings, GDP growth, and the index of economic freedom, however, on the other hand there is negative relationship between capital outflows and the index of political rights and civil liberties.

Originality/Value: Investment security management depends on institutions and institutional infrastructure as well as the ability to stimulate investment in the country. Reducing trade barriers and opening up the economy also contributes to increase investment in the country. Over the past ten years, investments in countries in transition have declined considerably due to weak investment security management.
\end{abstract}

Keywords: Investment security, transition economy, investment flows, economic growth.

JEL code: A13, D74, E22, O10.

Paper Type: Research article.

\footnotetext{
${ }^{1}$ Department of Production and Investment Management, Faculty of Agricultural

Management, National University of Life and Environmental Sciences of Ukraine, Kyiv,

Ukraine; E-mail: tanyaskyba@ukr.net

${ }^{2}$ Department of Science of Law, Polissya National University, Zhytomyr, Ukraine;

E-mail: ChernyshRF@gmail.com

${ }^{3}$ As in 1: E-mail: s-anja@ukr.net

${ }^{4}$ As in 1: E-mail: $\underline{\text { Tania_vl@ukr.net }}$

${ }^{5}$ Finance Department, Educational and Scientific Institute of Economics and Management, National University "Lviv Polytechnic", Lviv, Ukraine; E-mail: oksikurylo@gmail.com
} 


\section{Introduction}

Scientific research in the field of economic security of the state is actualized in the context of transformational shifts. At the same time, the processes of ensuring investment security are of particular importance, since ensuring is an important condition for the sustainable economic development of the country. Ensuring investment security ultimately provides for the formation of a rational economic strategy of the state, that is, the formation of an economic development strategy based on the balance of economic interests of all participants in investment activities that ensure constant and sustainable economic growth.

So, one of the main characteristics of effective investment security management is the country's economic growth. The main criterion for sufficient investment security is the competitiveness of the economy. Based on the fact that the criterion of economic security is to maintain adequate conditions of life (economic growth, wellbeing of the population), the material basis for this is a certain level of investment and investment security.

\section{Literature Review}

The mechanism for ensuring investment security will be considered as a system of organizational, economic, institutional and legal measures to influence the state's economic environment, which encourages domestic and foreign investors to ensure a level of investment in the economy that would guarantee its expanded reproduction and protection of national economic interests, as well as timely detection, prevention and elimination of threats to the investment security of the state (Bondaruk and Bondaruk, 2019; Basarir and Yilmaz, 2019; Rupeika-Apoga et al., 2018).

A theoretical approach, which links the level of development and Foreign Direct Investment (FDI), is the so-called 'investment development path model' (IDP). Foreign direct investment theories are concerned with identifying the reasons for making investments outside the country, or the impact of investments on the countries in which investors place funds (Thalassinos et al., 2015). The works of Buiter et al. (1997), Popov (1999), Mah and Tamulaitis (2000a; 2000b), Smarzynska-Javorcik (2002), Brada (2003), Kostevc et al. (2007), Dang (2012), Kalotay (2017), Altzinger et al. (2019), Svetličič and Bellak (2019), and Jindrichovska et al. (2020) are devoted to the study of various aspects of investment management in countries with transition economy.

Popov (1999) has examined the impact of investing on the economic development of the countries with transition economy, based on changes in GDP in transition. Differences in investment performance are related to different marginal productivity of the capital, not to investment models. It is revealed that a higher level of investment contributes to greater restructuring. There is a positive relationship between the ratio of exports to GDP and capital productivity. 
Dang (2012) examines the impact of the institutional environment on investing in transition economies during transitional period. For this, the political component was measured by the Freedom House's (2019). Political Rights and Civil Liberties indexes, the economic component by the Index of Economic Freedom compiled by the Heritage Foundation (2020), the European Bank for Reconstruction and Development's transition index (UNCTAD, 2017; 2018). The overall positive impact of economic measures on the level of investment, economic growth, savings, and financial sector development on investment in transition economies have been identified.

\section{Data and Methodology}

According to UNCTAD (n./d.) classification, 18 countries are included in transition stage, namely: Albania, Armenia, Azerbaijan, Belarus, Bosnia and Herzegovina, Georgia, Kazakhstan, Kyrgyzstan, Montenegro, North Macedonia, the Republic of Moldova, the Russian Federation, Serbia, Tajikistan, Turkmenistan, Ukraine and Uzbekistan. Notably, the group 'transition economies' was established to take account of the particular circumstances of that group of economies which have been shaped by socialism and now they are in transition to a market economy.

Data from the World Bank for the countries with transition economy are used to analyze investment security for the period 2008-2018 for the following countries: Albania, Armenia, Azerbaijan, Belarus, Bosnia and Herzegovina, Georgia, Kazakhstan, Kyrgyz Republic, Montenegro, North Macedonia, the Republic of Moldova, the Russian Federation, Serbia, Tajikistan, Ukraine and Uzbekistan. Data for Turkmenistan are not available for the period 2008-2018 for almost all indicators selected for evaluation.

The following indicators are selected for analysis in this study: Foreign direct investment (The World Bank, 2018a), net outflows (BoP, current US\$) and the \% of GDP, Gross capital formation (\% of GDP) (The World Bank, 2018d), Gross savings (\% of GDP) (The World Bank, 2018c), GDP growth (annual \%) (The World Bank, 2018 b). Descriptive statistics have been used for the analysis of the indicators.

\section{Results and Discussion}

Over the last ten years, the volume of investments from countries with transition economy has declined. In 2008 the average volume of investments was 4113.6 million US\$, while in 2018 dropped to 1832.5 million US\$ with significant variations within countries (7984.7 million US\$). In Albania, Kyrgyz Republic, Tajikistan, investment flows from the countries are either minimal or negative, that is, there is a small capital outflow. In Azerbaijan, Armenia, Georgia, Russia, Serbia, Ukraine, investment flows from the country are positive with variations in certain periods. 
Table 1. FDI, net outflows (current mUS\$) in transition economies in 2008-2018

\begin{tabular}{|l|c|c|c|c|c|c|}
\hline Country Name & 2008 & 2015 & 2016 & 2017 & 2018 & $\begin{array}{c}\text { Average growth } \\
2008-2018, \%\end{array}$ \\
\hline Albania & 371,6 & 79,3 & 7,0 & $-106,2$ & $-6,6$ & $-149,36 \%$ \\
\hline Armenia & 30,5 & 28,8 & 70,5 & 29,1 & 7,0 & $66,71 \%$ \\
\hline Azerbaijan & 4527,6 & 3209,4 & 2573,6 & 2564,4 & 1760,9 & $-0,83 \%$ \\
\hline $\begin{array}{l}\text { Bosnia and } \\
\text { Herzegovina }\end{array}$ & 39,4 & 94,7 & 0,2 & 94,9 & 32,9 & $4943,17 \%$ \\
\hline Belarus & 30,6 & 106,6 & 122,9 & 67,8 & 41,3 & $32,89 \%$ \\
\hline Georgia & 173,6 & 315,7 & 411,8 & 204,9 & 291,8 & $-79,83 \%$ \\
\hline Kazakhstan & 3704,1 & 3316,4 & 3474,6 & 956,5 & $-4711,1$ & $-61,60 \%$ \\
\hline Kyrgyz Republic & $-0,1$ & 135,0 & 40,3 & $-29,1$ & $-1,7$ & $-845,43 \%$ \\
\hline Moldova & 31,2 & 7,3 & 13,3 & 11,1 & 35,3 & $14,06 \%$ \\
\hline North Macedonia & 11,2 & 66,3 & 200,0 & 182,2 & $-60,5$ & $50,96 \%$ \\
\hline Montenegro & 110,3 & 12,4 & $-184,8$ & 11,1 & 106,6 & $-94,56 \%$ \\
\hline The Russian & 55662,6 & 22085,1 & 22314,3 & 36757,0 & 31376,9 & $3,24 \%$ \\
\hline Federation & 328,5 & 344,3 & 252,4 & 149,5 & 358,1 & $36,85 \%$ \\
\hline Serbia & 0,0 & 0,0 & 35,1 & 122,7 & $-28,3$ & - \\
\hline Tajikistan & 797,0 & 38,0 & 173,0 & 234,0 & 116,0 & $97,27 \%$ \\
\hline Ukraine & 0,0 & 0,0 & 5,8 & 9,0 & 1,9 & - \\
\hline Uzbekistan & 4113,6 & 1864,9 & 1844,4 & 2578,7 & 1832,5 & - \\
\hline Average, m US & $-0,1$ & 0,0 & $-184,8$ & $-106,2$ & $-4711,1$ & - \\
\hline Minimum & 55662,6 & 22085,1 & 22314,3 & 36757,0 & 31376,9 & - \\
\hline Maximum & 13814,8 & 5499,5 & 5553,1 & 9137,4 & 7984,7 & - \\
\hline Standard deviation & & & &
\end{tabular}

Source: Authors' calculations.

Net inflows to transition economies also declined on average in 2008-2018 from 7576.2 million US\$ to 1491.8 million US\$, which indicates a decrease in the efficiency of investment security management (Table 2). In fact, the largest volumes of investments come to Russia, Azerbaijan, Kazakhstan, Serbia, Ukraine. There are significant variations across countries, with average growth rates for 2008-2018, being positive. It should be noted that Ukraine needs to intensify its efforts to return investment resources to the national economy and the internal market, since the internal investment reserves are not enough to bring the economy out of the crisis and ensure its stable growth in the long term.

Table 2. FDI, net inflows (current mUS\$) in transition economies in 2008-2018

\begin{tabular}{|l|c|c|c|c|c|c|}
\hline Country Name & 2008 & 2015 & 2016 & 2017 & 2018 & $\begin{array}{c}\text { Average growth } \\
2008-2018, \%\end{array}$ \\
\hline Albania & 1253,1 & 989,6 & 1044,4 & 1022,8 & 1207,0 & $0,79 \%$ \\
\hline Armenia & 943,7 & 184,1 & 333,7 & 250,9 & 254,1 & $-6,02 \%$ \\
\hline Azerbaijan & 3986,8 & 4047,6 & 4499,7 & 2867,5 & 1403,0 & $-2,61 \%$ \\
\hline $\begin{array}{l}\text { Bosnia and } \\
\text { Herzegovina }\end{array}$ & 1004,9 & 383,1 & 282,8 & 462,7 & 485,5 & $19,01 \%$ \\
\hline Belarus & 2187,9 & 1652,3 & 1246,9 & 1276,3 & 1474,9 & $10,23 \%$ \\
\hline Georgia & 1596,7 & 1672,1 & 1570,5 & 1829,9 & 1184,1 & $4,14 \%$ \\
\hline Kazakhstan & 16818,9 & 6577,8 & 17221,0 & 4712,6 & 208,1 & $-4,92 \%$ \\
\hline Kyrgyz Republic & 377,0 & 1144,1 & 619,2 & $-107,2$ & 46,6 & $10,05 \%$ \\
\hline Moldova & 726,6 & 216,2 & 94,8 & 160,8 & 232,0 & $-0,13 \%$ \\
\hline
\end{tabular}




\begin{tabular}{|l|c|c|c|c|c|c|} 
North Macedonia & 611,7 & 296,6 & 549,4 & 380,7 & 674,5 & $44,67 \%$ \\
\hline Montenegro & 975,1 & 699,7 & 226,7 & 560,3 & 485,6 & $8,29 \%$ \\
\hline Russian Federation & 74782,9 & 6853,0 & 32538,9 & 28557,4 & 8784,9 & $17,95 \%$ \\
\hline Serbia & 4055,8 & 2343,1 & 2355,2 & 2894,6 & 4107,3 & $18,81 \%$ \\
\hline Tajikistan & 486,6 & 454,0 & 241,6 & 185,8 & 220,9 & $3,51 \%$ \\
\hline Ukraine & 10700,0 & 3050,0 & 3441,0 & 2827,0 & 2476,0 & $12,16 \%$ \\
\hline Uzbekistan & 711,3 & 66,5 & 1662,6 & 1797,3 & 624,3 & $233,13 \%$ \\
\hline Average, million US & 7576,2 & 1914,4 & 4245,5 & 3105,0 & 1491,8 & - \\
\hline Minimum & 377,0 & 66,5 & 94,8 & $-107,2$ & 46,6 & - \\
\hline Maximum & 74782,9 & 6853,0 & 32538,9 & 28557,4 & 8784,9 & - \\
\hline Standard deviation & 18470,4 & 2184,8 & 8615,7 & 6919,2 & 2207,5 & - \\
\hline
\end{tabular}

Source: Authors's calculations.

On average, net investment inflows account for 3.5\% of GDP. At the same time, the minimum value of the indicator is in countries where the level of political rights and civil liberties is lower or where the level of economic freedom is lower. Decreasing freedom rating reduces net investment inflows to countries (Figure 1).

Figure 1. FDI, net inflows (\% of GDP) and Freedom Rating in transition economies in 2018

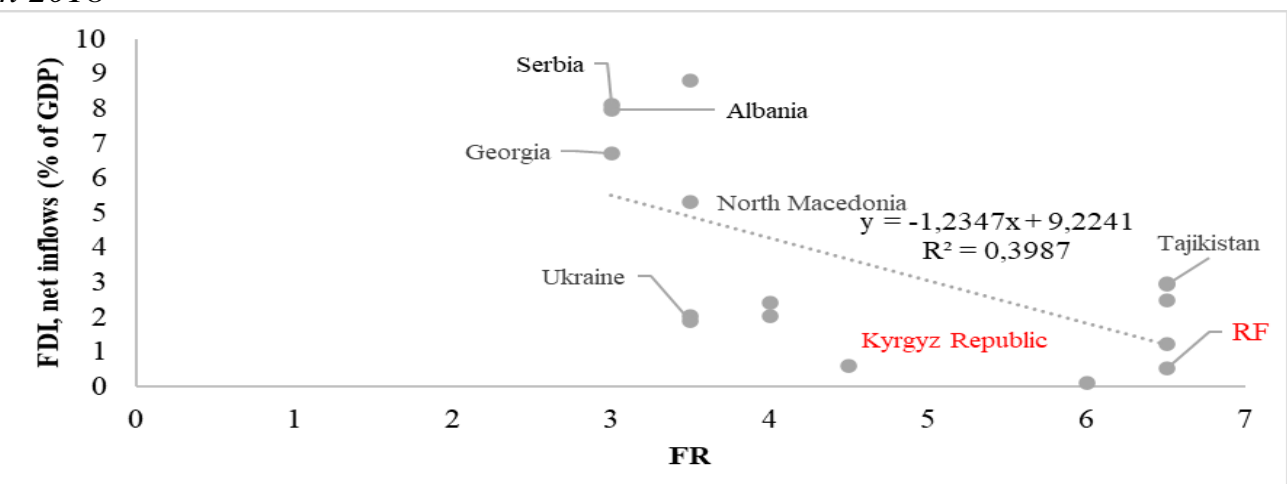

\section{Source: Authors's calculations.}

At the same time, there is a similar situation with investment outflows, high capital outflows in countries with low levels of political rights and civil liberties, economic freedom, but it is difficult to track such tendencies (Table 3). 
Table 3. FDI flows, gross capital formation, GDP growth, gross savings, freedom rating and economic freedom in transition economies in $2018^{6}$

\begin{tabular}{|c|c|c|c|c|c|c|c|c|c|}
\hline Country Name & 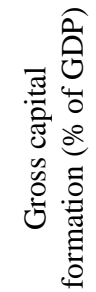 & $\begin{array}{l}\text { 0 } \\
0 \\
0 \\
0 \\
0 \\
0 \\
0 \\
0 \\
0 \\
0 \\
0 \\
0 \\
0 \\
0\end{array}$ & 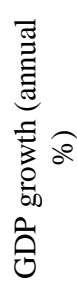 & 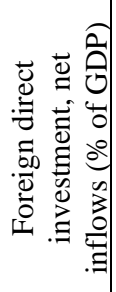 & 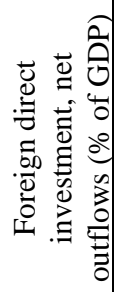 & 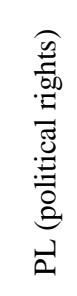 & 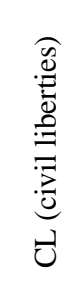 & 蒆 & 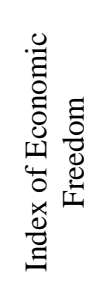 \\
\hline Alban & $-6,64$ & 6,23 & 4,15 & 7,99 & $-0,04$ & 3,00 & 3,00 & 3,00 & 66,50 \\
\hline Arme & 22,40 & 3,61 & 5,20 & 2,04 & 0,06 & 00 & 00 & 00 & 67,70 \\
\hline Azerb & 20,08 & 32,97 & 1,41 & 2,99 & 3,75 & 7,00 & 5,00 & 5,50 & 65,40 \\
\hline $\begin{array}{l}\text { Bosnia and } \\
\text { Herzegovina }\end{array}$ & 20,91 & 15,18 & 3,62 & 2,41 & 0,16 & 4,00 & 4,00 & 4,00 & 61,90 \\
\hline Belarus & 27,50 & 28,79 & 3,05 & 2,47 & 0,07 & 7,00 & 6,00 & 6,50 & 57,90 \\
\hline Georgia & 28,12 & 21,05 & 4,80 & 6,73 & 1,66 & 3,00 & 3,00 & 3,00 & 75,90 \\
\hline Kazakhstan & 23,84 & 30,24 & 4,10 & 0,12 & $-2,63$ & 7,00 & 5,00 & 6,00 & 65,40 \\
\hline Kyrgyz Republic & 35,38 & 28,10 & 3,50 & 0,58 & $-0,02$ & 5,00 & 4,00 & 4,50 & 62,30 \\
\hline Moldova & 25,62 & 14,95 & 3,40 & 2,03 & 0,31 & 3,00 & 4,00 & 3,50 & 59,10 \\
\hline North Macedonia & 32,99 & 33,02 & 2,66 & 5,32 & $-0,48$ & 4,00 & 3,00 & 3,50 & 71,10 \\
\hline Montenegro & 31,91 & 14,90 & 5,08 & 8,82 & 1,94 & 4,00 & 3,00 & 3,50 & 60,50 \\
\hline The Russian Federation & 22,73 & 30,19 & 2,25 & 0,53 & 1,89 & 7,00 & 6,00 & 6,50 & 58,90 \\
\hline Serbia & 22,67 & 18,63 & 4,39 & 8,12 & 0,71 & 3,00 & 3,00 & 3,00 & 63,90 \\
\hline Tajikistan & $-28,29$ & 23,26 & 7,30 & 2,94 & $-0,38$ & 7,00 & 6,00 & 6,50 & 55,60 \\
\hline Ukraine & 18,77 & 10,62 & 3,34 & 1,89 & 0,09 & 3,00 & 4,00 & 3,50 & 52,30 \\
\hline Uzbekistan & 40,18 & 41,90 & 5,12 & 1,24 & 0,00 & 7,00 & 6,00 & 6,50 & 53,30 \\
\hline Average & 21,13 & 23,35 & 3,96 & 3,51 & 0,44 & 4,88 & 4,38 & 4,63 & 62,36 \\
\hline Minimum & $-28,29$ & 10,62 & 1,41 & 0,12 & $-2,63$ & 3,00 & 3,00 & 3,00 & 52,30 \\
\hline Maximum & 40,18 & 41,90 & 7,30 & 8,82 & 3,75 & 7,00 & 6,00 & 6,50 & 75,90 \\
\hline Standa & 16,67 & 9,02 & 1,39 & 2,91 & 1,39 & 1,78 & 1,26 & 1,49 & 6,33 \\
\hline
\end{tabular}

Source: Authors's calculations.

Correlation analysis indicates a positive relationship between investment outflows and gross capital formation (0.164), gross savings (0.015), GDP growth (0.437), economic freedom index (0.322), but a negative relationship between capital outflows and the political rights index and civil liberties (Table 4).

\footnotetext{
${ }^{6}$ Political Rights and Civil Liberties Ratings - A country or territory is assigned two ratings: one for political rights and one for civil liberties - based on its total scores for the political rights and civil liberties questions. Each rating of 1 to 7 , with 1 representing the greatest degree of freedom and 7 the smallest degree of freedom, corresponds to a specific range of total scores (see Tables 1 and 2).
} 
Table 4. Correlation matrix for the variables

\begin{tabular}{|c|c|c|c|c|c|c|c|c|c|}
\hline & 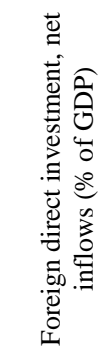 & 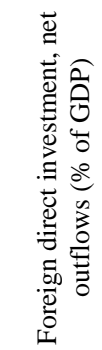 & 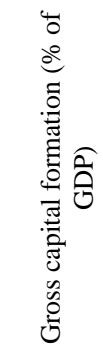 & 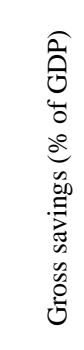 & 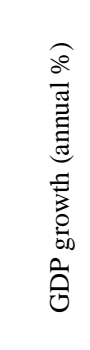 & 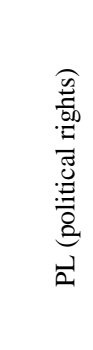 & 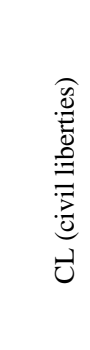 & $\frac{\alpha}{I}$ & 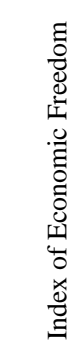 \\
\hline $\begin{array}{l}\text { Foreign direct } \\
\text { investment, net inflows } \\
\text { (\% of GDP) }\end{array}$ & 1,000 & & & & & & & & \\
\hline $\begin{array}{l}\text { Foreign direct } \\
\text { investment, net } \\
\text { outflows (\% of GDP) }\end{array}$ & 0,500 & 1,000 & & & & & & & \\
\hline $\begin{array}{l}\text { Gross capital formation } \\
\text { (\% of GDP) }\end{array}$ & 0,164 & 0,430 & 1,000 & & & & & & \\
\hline $\begin{array}{l}\text { Gross savings (\% of } \\
\text { GDP) }\end{array}$ & 0,015 & 0,274 & 0,462 & 1,000 & & & & & \\
\hline GDP growth (annual \%) & 0,437 & 0,123 & 0,069 & 0,267 & 1,000 & & & & \\
\hline PL (political rights) & $-0,238$ & 0,162 & 0,166 & 0,814 & 0,293 & 1,000 & & & \\
\hline CL (civil liberties) & $-0,281$ & 0,194 & 0,118 & 0,712 & 0,318 & 0,931 & 1,000 & & \\
\hline FR & $-0,260$ & 0,178 & 0,147 & 0,783 & 0,310 & 0,987 & 0,978 & 1,000 & \\
\hline $\begin{array}{l}\text { Index of Economic } \\
\text { Freedom }\end{array}$ & 0,322 & 0,088 & 0,217 & 0,414 & 0,426 & 0,307 & 0,362 & 0,340 & 1,000 \\
\hline
\end{tabular}

Managing a country's investment security depends on a number of factors as labor productivity, the country's infrastructure, foreign and domestic interest rates, inflation, currency depreciation, and the country's economic growth. The analysis of investment flows shows that economic growth and gross accumulated capital in transition economies have a negative impact on capital inflows.

Therefore, the main problems for transition economies, which reduce investment attractiveness and force investors from the internal market or delay entry into it, are:

$>$ low efficiency of the mechanism of protection of foreign investors and investments, which is accompanied by raider seizures of property (for example, in Ukraine from national business units according to the World Bank rating), Ukraine in 2016 ranked only the 80th place in this indicator among the countries of the world, and during the study period fluctuations were within $80-155$ places;

$>$ high level of shadow and criminal economy;

$>$ there is no effective system of antitrust legislation, which leads to significant violations and the formation of monopoly business associations in the domestic market;

$>$ low level of intellectual property protection (the international property rights index of Ukraine was 4.0, which puts it on the 117th place among the countries of the world); 
$>$ corruption, according to the world corruption promotion rating, countries with transition economy hold the last places in the ranking;

$>$ lack of effective mechanisms for attracting and stimulating foreign investment, which is confirmed by frequent changes in the country's strategic development priorities (more than five times since independence);

$>$ complex and complicated system of permits leads to an increase in the time and cost of entering the domestic market;

$>$ high frequency of changes in legislation, especially in the tax and economic spheres, which makes it difficult to carry out financial and economic activities in countries;

$>$ poor infrastructure, especially with regard to the quality of roads and rail transport;

$>$ low income level of the population, which reduces the ability of investors to operate in the country and reduces the market capacity in monetary terms.

The institutional environment is an important factor, which is closely related to the management aspect of investment flows, privatization, budget deficit, and labor costs. The weak and undeveloped institution of property rights and investor protection is the reason for the low level of investment flows to the country, especially in high-tech industries. As a result, investors focus on projects in the distribution sector, where the risks are less and the procedures for withdrawing funds are easier, compared to the production sectors of the economy.

Acceleration of macro-stabilization policies, price liberalization, removal of trade barriers, and currency convertibility ensure a rapid transition to a market economy. Freedom in the activities of economic agents has a positive effect on noninflationary economic growth, and therefore has a positive effect on investment capital inflows. In developed countries, large amounts of investment are provided by macroeconomic stabilization measures (for example, tight fiscal and monetary policies), and increased competition, which in general contributed to improving the overall efficiency of resource use. Ensuring competitiveness and industrial restructuring in the country affect investment flows. Consequently, the nationalistic approach to resource allocation and the complexity of relations between the central and local authorities cause insufficient incentives for investment in the country.

\section{Conclusion}

The results of the investment flows' analysis indicate a low level of investment security in countries with transition economy. There are significant differences between countries in the transition from socialism to market economy, and hence differences in investment flows. As a result, the level of economic growth, competitiveness, and integration into world markets differs significantly. Transformation strategies can explain differences between countries. It is revealed that the level of political rights, civil liberties and economic freedom significantly affect investment flows. Investment security management depends on the institutions 
and institutional infrastructure and its ability to stimulate investment in the country. Reducing trade barriers and opening up the economy also contributes to increased investment in the country. The main disadvantages of managing investment security in transition economies are low institutional capacity in such areas as the antitrust law system, the institute for intellectual property protection, corruption and the judicial system, mechanisms for attracting and stimulating foreign investment, the permit system, legislation, and lack of infrastructure.

\section{References:}

Altzinger, W., Bellak, C., Jaklic, A., Rojec, M. 2003. Direct versus indirect foreign investment from transition economies: is there a difference in parent company/home country impact? In Svetlicic, M. and Rojec M. (Eds.), Facilitating Transition by Internationalization: Outward Direct Investment from Central European Economies in Transition, Ashgate, Aldershot, 91-110.

Basarir, C., Yilmaz, O. 2019. Herd Behavior and its Effects on the Purchasing Behavior of Investors. In: S. Grima, E. Ozen, H. Boz, J. Spiteri and E.I. Thalassinos, (eds.), Contemporary Issues in Behavioral Finance, Emerald Series, Contemporary Issues in Economics and Financial Analysis, Volume 101, 217-228, Emerald Publishing Limited, UK, ISSN: 1569-3759, doi:10.1108/S1569-375920190000101015.

Bondaruk, T.H., Bondaruk, O.S. 2019. Investment security of the state: strategic goals and mechanism of security. Ukraine Statictics, 2, 83-91.

Brada, J.C. 2003. Privatization, Restructuring, Corporate Governance and the Behaviour of Firms in Transition Economies. In Stüting, H.J., Dorow, W., Claassen, F., Blazejewski, S. (Eds.), Change Management in Transition Economies, 55-70. Palgrave Macmillan, London, doi:10.1057/9781403937841_5.

Buiter, W.H., Lago, R., Rey, H. 1997. A portfolio approach to a cross-sectoral and crossnational investment strategy in transition economies. The Economics of Transition, 5(1), 63-96. https://doi.org/10.1111/j.1468-0351.1997.tb00004.x.

Dang, V. 2012. Institutional Determinants of Investment in Transition Economies. SSRN Electronic Journal. https://doi.org/10.2139/ssrn.2025328.

Freedom House. 2019. Countries and Territories. Available at https://freedomhouse.org/report/countries-world-freedom-2019.

Heritage Foundation. 2020. Country Rankings. Available at https://www.heritage.org/index/ranking.

Jindrichovska, I., Ugurlu, E., Thalassinos, I.E. 2020. Exploring the Trend of Czech FDIs and their Effect to Institutional Environment. International Journal of Economics and Business Administration, 8(1), 94-108. DOI: 10.35808/ijeba/411

Kalotay, K. 2017. Outward Foreign Direct Investment from Economies in Transition in a global context. In Steger, T., Lang, R., Rybnikova, I. (Eds.), Management in CEE Countries Between 1996 and 2016, 155-173. Nomos, Baden-Baden. doi:10.5771/9783845286037-158.

Kostevc, Č., Redek, T., Sušjan, A. 2007. Foreign Direct Investment and Institutional Environment in Transition Economies. Transition Studies Review, 14(1), 40-54. doi:10.1007/s11300-007-0140-5.

Mah, J.S., Tamulaitis, D. 2000a. A Note on Investment Incentives in the WTO and the Transition Economies. Post-Communist Economies, 12(1), 119-130. doi:10.1080/14631370050002701. 
Mah, J.S., Tamulaitis, D. 2000b. Investment Incentives in the Central and Eastern European Transition Economies. The Journal of World Investment \& Trade, 1(1), 225-241. https://doi.org/10.1163/221190000x00078.

Popov, V. 1999. Investment, Restructuring and Performance in Transition Economies. PostCommunist Economies, 11(4), 445-462. https://doi.org/10.1080/14631379995832.

Rupeika-Apoga, R., Zaidi, H.S., Thalassinos, E.Y., Thalassinos, I.E. 2018. Bank Stability: The Case of Nordic and Non-Nordic Banks in Latvia. International Journal of Economics and Business Administration, 6(2), 39-55, DOI: 10.35808/ijeba/156.

Smarzynska-Javorcik, B. 2004. The composition of foreign direct investment and protection of intellectual property rights: Evidence from transition economies. European Economic Review, 48(1), 39-62.

Svetličič, M., Bellak, C. 2019. Investment Development Path of Small Economies: Comparative Evaluation of Austria and Slovenia. In Rojec, M. (Ed.), Facilitating Transition by Internationalization. Routledge, London. https://doi.org/10.4324/9781315255583-2.

Thalassinos, I.E., Thalassinos, E.P., Venedictova, B., Yordanov, V. 2015. Currency Board Arrangement Capital Structure Macro-Financial Diagnostic. SSRN-id2624333.pdf.

The World Bank. 2018a. Foreign direct investment, net inflows (BoP, current US\$). Available at https://data.worldbank.org/indicator/BX.KLT.DINV.CD.WD?view=chart.

The World Bank. 2018b. GDP growth (annual \%). Available at https://data.worldbank.org/indicator/NY.GDP.MKTP.KD.ZG?view=chart.

The World Bank. 2018c. Gross savings (\% of GDP). Available at https://data.worldbank.org/indicator/NY.GNS.ICTR.ZS?view=chart.

The World Bank. 2018d. Gross capital formation (\% of GDP). Available at https://data.worldbank.org/indicator/NE.GDI.TOTL.ZS?view=chart.

UNCTAD. 2017. Transition economies. In World Investment Report 2017: Investment and the Digital Economy. UN, New York. https://doi.org/10.18356/2dd775a2-en.

UNCTAD. 2018. Transition economies. In World Investment Report 2018: Investment and New Industrial Policies. UN, New York. https://doi.org/10.18356/dc58d4e1-en.

UNCTAD. n./d. Country classification. Development status groups and composition. Available at https://unctadstat.unctad.org/en/classifications.html. 